\title{
Diversity of cultivated and metabolically active aerobic anoxygenic phototrophic bacteria along an oligotrophic gradient in the Mediterranean Sea
}

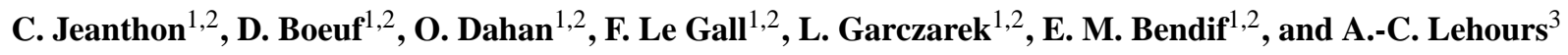 \\ ${ }^{1}$ Observatoire Océanologique de Roscoff, UMR7144, INSU-CNRS - Groupe Plancton Océanique, 29680 Roscoff, France \\ ${ }^{2}$ UPMC Univ Paris 06, UMR7144, Adaptation et Diversité en Milieu Marin, Station Biologique de Roscoff, \\ 29680 Roscoff, France \\ ${ }^{3}$ CNRS, UMR6023, Microorganismes: Génome et Environnement, Université Blaise Pascal, 63177 Aubière Cedex, France
}

Received: 21 April 2011 - Published in Biogeosciences Discuss.: 5 May 2011

Revised: 7 July 2011 - Accepted: 8 July 2011 - Published: 20 July 2011

\begin{abstract}
Aerobic anoxygenic phototrophic (AAP) bacteria play significant roles in the bacterioplankton productivity and biogeochemical cycles of the surface ocean. In this study, we applied both cultivation and mRNA-based molecular methods to explore the diversity of AAP bacteria along an oligotrophic gradient in the Mediterranean Sea in early summer 2008. Colony-forming units obtained on three different agar media were screened for the production of bacteriochlorophyll- $a$ (BChl- $a$ ), the light-harvesting pigment of AAP bacteria. BChl- $a$-containing colonies represented a low part of the cultivable fraction. In total, 54 AAP strains were isolated and the phylogenetic analyses based on their 16S rRNA and pufM genes showed that they were all affiliated to the Alphaproteobacteria. The most frequently isolated strains belonged to Citromicrobium bathyomarinum, and Erythrobacter and Roseovarius species. Most other isolates were related to species not reported to produce BChl- $a$ and/or may represent novel taxa. Direct extraction of RNA from seawater samples enabled the analysis of the expression of pufM, the gene coding for the $\mathrm{M}$ subunit of the reaction centre complex of aerobic anoxygenic photosynthesis. Clone libraries of $p u f M$ gene transcripts revealed that most phylotypes were highly similar to sequences previously recovered from the Mediterranean Sea and a large majority ( $94 \%)$ was affiliated to the Gammaproteobacteria. The most abundantly detected phylotypes occurred in the western and eastern Mediterranean basins. However, some were exclusively
\end{abstract}

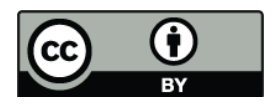

Correspondence to: C. Jeanthon (jeanthon@ @b-roscoff.fr) detected in the eastern basin, reflecting the highest diversity of pufM transcripts observed in this ultra-oligotrophic region. To our knowledge, this is the first study to document extensively the diversity of AAP isolates and to unveil the active AAP community in an oligotrophic marine environment. By pointing out the discrepancies between culture-based and molecular methods, this study highlights the existing gaps in the understanding of the AAP bacteria ecology, especially in the Mediterranean Sea and likely globally.

\section{Introduction}

Aerobic anoxygenic phototrophic (AAP) bacteria are photoheterotrophs that require oxygen for their growth and for bacteriochlorophyll- $a$ (BChl- $a$ ) synthesis. Given their capability of harvesting light energy, they represent an important fraction of the bacterioplankton in freshwater and marine illuminated environments (Kolber et al., 2000, 2001; Béjà et al., 2002; Jiao et al., 2007; Yutin et al., 2007; Masin et al., 2008; Jiang et al., 2009). AAP bacteria were found to be widely distributed in the marine environment representing about $1.5-5 \%$ of total bacteria in the euphotic zone of the ocean (Schwalbach and Fuhrman, 2005; Cottrell et al., 2006; Sieracki et al., 2006; Jiao et al., 2007). On the other hand, $\mathrm{BChl}-a$ measurements suggested that AAP bacteria may constitute a very dynamic part of the marine bacterial community contributing significantly to the cycling of organic carbon in the upper ocean (Koblizek et al., 2007). A global ocean study showed that the maximum AAP bacterial diversity was found in oligotrophic areas, whereas AAP bacterial

Published by Copernicus Publications on behalf of the European Geosciences Union. 
abundance followed the opposite trend, positively correlated to the concentration of chlorophyll- $a$ (Jiao et al., 2007).

The Mediterranean Sea is one of the most oligotrophic oceanic systems and is characterized by a longitudinal gradient of oligotrophy increasing eastwards. The different trophic conditions available in the Mediterranean Sea offer a unique context to link nutrient availability, trophic status and functioning of the food web to the dynamics of photoheterotrophic populations. The $3000 \mathrm{~km}$ transect surveyed by the BOUM (Biogeochemistry from the Oligotrophic to the Ultraoligotrophic Mediterranean) cruise during the stratification period in early summer 2008 provided an opportunity to better understand the distribution pattern of abundance and diversity of AAP bacteria in this environment. In a companion paper, Lamy et al. (2011) demonstrated that concentrations of BChl- $a$ and AAP bacterial abundance decreased from the western to the eastern basins of the Mediterranean Sea and were linked with concentrations of Chl- $a$, nutrient and dissolved organic carbon. Interestingly, the BChl- $a$ content per cell was significantly higher in the ultra-oligotrophic eastern basin than in the two other basins suggesting that reliance on phototrophy varied along the oligotrophic gradient and that nutrient and/or carbon limitation favors BChl- $a$ synthesis.

Molecular analyses based on the $p u f M$ gene encoding the M-subunit of the photosynthetic reaction center have explored AAP bacterial diversity using the polymerase chain reaction (PCR) (Béjà et al., 2002; Yutin et al., 2005; Jiao et al., 2007), denaturing/temperature gradient gel electrophoresis (DGGE/TGGE) (Yutin et al., 2008; Lehours et al., 2010), terminal restriction fragment length polymorphism (T-RFLP) (Ranchou-Peyruse et al., 2006) and metagenomic analysis (Yutin et al., 2007). Although these DNA-based approaches have given insight into the diversity of AAP bacteria, analysis of relevant functional communities is still a challenge, as DNA could be stable in resting cells and even dead cells and may also be present as extracellular DNA. In contrast, RNA is highly labile and rRNA levels, and therefore ribosome numbers, have been correlated with cellular activity (Kramer and Singleton, 1992, 1993). Moreover, studies of cultured bacteria have identified that mRNA is typically short-lived having a half-life of only a few minutes (Von Gabain et al., 1983). Thus, it has been argued that analysis of sequences derived from RNA rather than DNA templates potentially provide a more representative indication of the active members of the bacterial community and a strong indication of specific gene expression at the time of sampling (Pichard and Paul, 1993). Reverse transcription PCR (RT-PCR) approaches have been used to investigate gene expression and to identify active AAP bacteria in the environment (Béjà et al., 2002; Karr et al., 2003). Up to now, several DNA-based molecular studies have explored the diversity patterns of AAP bacteria in the Mediterranean Sea (Oz et al., 2005; Yutin et al., 2005, 2008; Lehours et al., 2010; Martinez-Garcia et al., 2010). However, only a very small number of AAP bacteria have been isolated from its surface waters so far and the examination of the taxa actively expressing $p u f M$ has never been conducted.

The aim of this study was to identify the cultivable fraction and active members of the AAP bacterial community along a large transect in the Mediterranean Sea during the stratification period through cultivation and mRNA-based techniques.

\section{Material and methods}

\subsection{Sampling}

Seawater samples were collected from 16 stations along a transect in the Mediterranean Sea (from the North of the Western Basin to the Levantine Basin) in June and July 2008 during the BOUM cruise aboard the R/V L'Atalante (Fig. 1). The sampled stations included fourteen short duration $(4 \mathrm{~h})$ stations (stations 1, 3, 5, 7, 9, 11, 13, 15, 17, 19, 21, 24, 25, 27) and three 4-day drifting stations (stations A, B and C) representative of low nutrient low chlorophyll (LNLC) conditions (Moutin et al., 2011). These three stations were located at the center of anticyclonic eddies in the western basin (station A), in the Ionian Sea (station B) and in the Levantine Sea (station C). Water samples were retrieved using 121 Niskin bottles fitted on a Rosette sampler equipped with conductivity, temperature and depth (CTD) sensors. For bacterial cultures, samples were kept in the dark and at $4{ }^{\circ} \mathrm{C}$ until processed (within one hour). Bacterioplankton cells for total RNA extraction were collected by filtering seawater from the same water sample used for the culture experiments. To limit the degradation of mRNA, small volumes of seawater $(\sim 11)$ were filtered as rapidly as possible, immediately upon retrieval of the CTD. The time from the start of filtration to storage in RNAlater was $15-20$ min. Briefly, the seawater was prefiltered in line through $47 \mathrm{~mm}$ diameter and $3 \mu \mathrm{m}$ pore size polycarbonate filters (Cyclopore, Whatman) before the final collection of bacterioplankton cells onto $25 \mathrm{~mm}$ diameter and $0.22 \mu \mathrm{m}$ pore size polycarbonate filters (Isopore, Millipore) using a four-head Masterflex peristaltic pump (Cole Parmer Instrument Company). Three filters per sample were processed and immediately transferred individually to a screwcap tube containing $1 \mathrm{ml}$ RNAlater (Ambion Inc., Austin, USA), frozen in liquid nitrogen and kept at $-80^{\circ} \mathrm{C}$ aboard the R/V L'Atalante. Samples were transported frozen in dry ice to the laboratory and stored at $-80^{\circ} \mathrm{C}$ until RNA extraction procedures.

\subsection{Culture media, strain isolation and identification}

Seawater samples collected at the surface $(3 \mathrm{~m})$ and at the deep chlorophyll maximum (DCM) were used to isolate AAP bacteria (Table 1). Colonies were obtained by spreading 50 to $100 \mu$ l of seawater samples on Marine Agar (Difco, Detroit, MI) and two low strength agar media referred here as MAD and MiA. MAD medium consisted in $0.5 \mathrm{~g}$ Bacto 


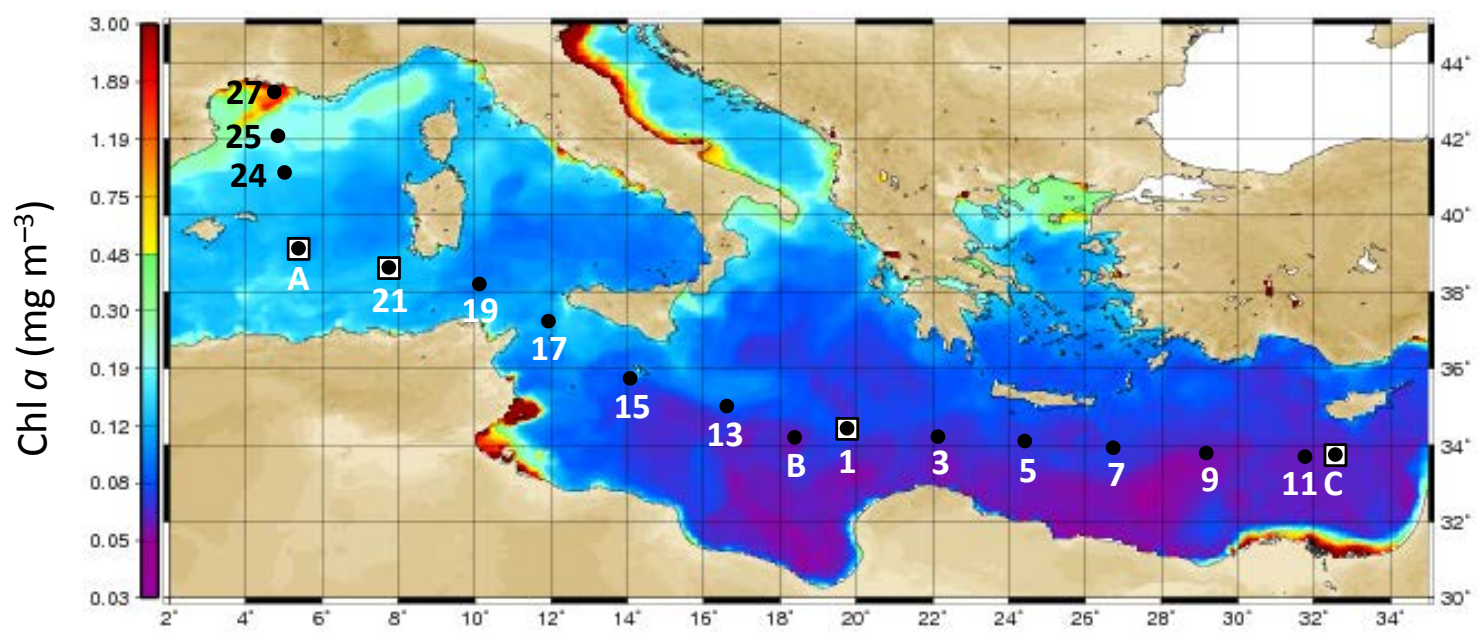

Fig. 1. Track of the BOUM cruise (16 June-20 July 2008) superimposed on the composite SeaWiFS image of the sea surface Chl- $a$ concentrations (June 2008, courtesy to E. Bosc). Symbol types represent analyses performed at sampled stations: black spheres ( $\bullet$ ) indicate stations where AAP isolation was attempted and white squares ( $\square$ ) indicate stations where RNA-based pufM libraries were additionally constructed.

Table 1. Location, depth, temperature and date of sampling, source and medium of isolation of cultivated Mediterranean AAP bacteria.

\begin{tabular}{|c|c|c|c|c|c|c|c|c|}
\hline Isolate $^{\mathrm{a}}$ & Station & Latitude & Longitude & $\begin{array}{r}\text { Depth } \\
(\mathrm{m})\end{array}$ & $\begin{array}{l}\text { Temp } \\
\left({ }^{\circ} \mathrm{C}\right)\end{array}$ & $\begin{array}{r}\text { Sampling } \\
\text { date }\end{array}$ & Source of isolation & $\begin{array}{l}\text { Isolation } \\
\text { medium }^{b}\end{array}$ \\
\hline RCC 1876 & 5 & $34^{\circ} 03^{\prime} \mathrm{N}$ & $24^{\circ} 30^{\prime} \mathrm{E}$ & 5 & 23 & 22 Jun 2008 & seawater & MAD \\
\hline RCC 1877 & 13 & $34^{\circ} 53^{\prime} \mathrm{N}$ & $16^{\circ} 42^{\prime} \mathrm{E}$ & 93 & 16 & 8 Jul 2008 & seawater & MAD \\
\hline RCC 1878-1882 & $\mathrm{B}$ & $34^{\circ} 08^{\prime} \mathrm{N}$ & $18^{\circ} 27^{\prime} \mathrm{E}$ & 5 & 27 & 6 Jul 2008 & seawater & $\mathrm{MiA}$ \\
\hline RCC 1883-1887 & $\mathrm{B}$ & $34^{\circ} 08^{\prime} \mathrm{N}$ & $18^{\circ} 27^{\prime} \mathrm{E}$ & 5 & 27 & 6 Jul 2008 & seawater & MAD \\
\hline RCC 1888 & 17 & $37^{\circ} 10^{\prime} \mathrm{N}$ & $12^{\circ} 00^{\prime} \mathrm{E}$ & 80 & 16 & 9 Jul 2008 & seawater & $\mathrm{MiA}$ \\
\hline RCC 1889 & 17 & $37^{\circ} 10^{\prime} \mathrm{N}$ & $12^{\circ} 00^{\prime} \mathrm{E}$ & 80 & 16 & 9 Jul 2008 & seawater & MAD \\
\hline RCC 1890-1894 & 21 & $38^{\circ} 38^{\prime} \mathrm{N}$ & $7^{\circ} 55^{\prime} \mathrm{E}$ & 85 & 15 & $11 \mathrm{Jul} 2008$ & seawater & MAD \\
\hline RCC $1895-1898$ & 21 & $38^{\circ} 38^{\prime} \mathrm{N}$ & $7^{\circ} 55^{\prime} \mathrm{E}$ & 85 & 15 & $11 \mathrm{Jul} 2008$ & seawater & $\mathrm{MiA}$ \\
\hline RCC 1899-1904 & $\mathrm{A}$ & $39^{\circ} 06^{\prime} \mathrm{N}$ & $5^{\circ} 21^{\prime} \mathrm{E}$ & 90 & 15 & $16 \mathrm{Jul} 2008$ & seawater & MAD \\
\hline RCC 1905-1906 & 24 & $41^{\circ} 05^{\prime} \mathrm{N}$ & $5^{\circ} 03^{\prime} \mathrm{E}$ & 5 & 22 & $18 \mathrm{Jul} 2008$ & seawater & MAD \\
\hline RCC 1907 & 27 & $43^{\circ} 13^{\prime} \mathrm{N}$ & $4^{\circ} 56^{\prime} \mathrm{E}$ & 5 & 18 & $19 \mathrm{Jul} 2008$ & seawater & MAD \\
\hline RCC 1908 & 27 & $43^{\circ} 13^{\prime} \mathrm{N}$ & $4^{\circ} 56^{\prime} \mathrm{E}$ & 5 & 18 & $19 \mathrm{Jul} 2008$ & seawater & MA \\
\hline RCC 1909 & 27 & $43^{\circ} 13^{\prime} \mathrm{N}$ & $4^{\circ} 56^{\prime} \mathrm{E}$ & 25 & 15 & $19 \mathrm{Jul} 2008$ & seawater & MAD \\
\hline RCC 1910 & 27 & $43^{\circ} 13^{\prime} \mathrm{N}$ & $4^{\circ} 56^{\prime} \mathrm{E}$ & 25 & 15 & $19 \mathrm{Jul} 2008$ & seawater & $\mathrm{MiA}$ \\
\hline RCC 1911 & A & $39^{\circ} 06^{\prime} \mathrm{N}$ & $5^{\circ} 21^{\prime} \mathrm{E}$ & 90 & 15 & $16 \mathrm{Jul} 2008$ & seawater & MAD \\
\hline RCC 1912-1913 & 24 & $41^{\circ} 05^{\prime} \mathrm{N}$ & $5^{\circ} 03^{\prime} \mathrm{E}$ & 5 & 22 & $18 \mathrm{Jul} 2008$ & seawater & $\mathrm{MiA}$ \\
\hline RCC 1914 & A & $39^{\circ} 06^{\prime} \mathrm{N}$ & $5^{\circ} 21^{\prime} \mathrm{E}$ & 100 & 15 & $14 \mathrm{Jul} 2008$ & Synechococcus culture obtained in $\mathrm{PRO} 2 / 5+\mathrm{NO}_{3}$ & MAD \\
\hline RCC 1915-1916 & A & $39^{\circ} 06^{\prime} \mathrm{N}$ & $5^{\circ} 21^{\prime} \mathrm{E}$ & 100 & 15 & $14 \mathrm{Jul} 2008$ & Synechococcus culture obtained in JM/100 & MAD \\
\hline RCC 1917 & A & $39^{\circ} 06^{\prime} \mathrm{N}$ & $5^{\circ} 21^{\prime} \mathrm{E}$ & 100 & 15 & $14 \mathrm{Jul} 2008$ & Osteococcus culture obtained in PRO2/5 & MAD \\
\hline RCC 1918 & 27 & $43^{\circ} 13^{\prime} \mathrm{N}$ & $4^{\circ} 56^{\prime} \mathrm{E}$ & 5 & 18 & $19 \mathrm{Jul} 2008$ & unidentified algal culture obtained in $\mathrm{PRO} 2 / 5$ & MAD \\
\hline RCC 1919 & 15 & $35^{\circ} 40^{\prime} \mathrm{N}$ & $14^{\circ} 06^{\prime} \mathrm{E}$ & 100 & 16 & 8 Jul 2008 & Pycnococcus culture obtained in $\mathrm{PRO} 2 / 5+\mathrm{NO}_{3}$ & MAD \\
\hline RCC 1920 & 27 & $43^{\circ} 13^{\prime} \mathrm{N}$ & $4^{\circ} 56^{\prime} \mathrm{E}$ & 5 & 18 & $19 \mathrm{Jul} 2008$ & mixed culture obtained in $\mathrm{PRO} 2 / 5+\mathrm{NO}_{3}$ & MAD \\
\hline RCC 1921-1922 & 27 & $43^{\circ} 13^{\prime} \mathrm{N}$ & $4^{\circ} 56^{\prime} \mathrm{E}$ & 5 & 18 & $19 \mathrm{Jul} 2008$ & Ochromonas culture obtained in $\mathrm{JM} / 100$ & MAD \\
\hline RCC 1923 & 27 & $43^{\circ} 13^{\prime} \mathrm{N}$ & $4^{\circ} 56^{\prime} \mathrm{E}$ & 5 & 18 & $19 \mathrm{Jul} 2008$ & mixed culture obtained in $\mathrm{PRO} 2 / 5$ & MAD \\
\hline RCC 1924 & 24 & $41^{\circ} 05^{\prime} \mathrm{N}$ & $5^{\circ} 03^{\prime} \mathrm{E}$ & 5 & 22 & $18 \mathrm{Jul} 2008$ & mixed culture obtained in $\mathrm{PRO} 2 / 5$ & MAD \\
\hline RCC 1925-1926 & 24 & $41^{\circ} 05^{\prime} \mathrm{N}$ & $5^{\circ} 03^{\prime} \mathrm{E}$ & 5 & 22 & $18 \mathrm{Jul} 2008$ & mixed culture obtained in $\mathrm{PRO} 2 / 5+\mathrm{NO}_{3}$ & MAD \\
\hline RCC 1927 & 15 & $35^{\circ} 40^{\prime} \mathrm{N}$ & $14^{\circ} 06^{\prime} \mathrm{E}$ & 25 & 22 & 8 Jul 2008 & mixed culture obtained in $\mathrm{PRO} 2 / 5$ & MAD \\
\hline RCC 1928 & $\mathrm{C}$ & $33^{\circ} 38^{\prime} \mathrm{N}$ & $32^{\circ} 39^{\prime} \mathrm{E}$ & 5 & 27 & 27 Jun 2008 & mixed culture obtained in $\mathrm{PRO} 2 / 5+\mathrm{NO}_{3}$ & MAD \\
\hline RCC 1929 & 24 & $41^{\circ} 05^{\prime} \mathrm{N}$ & $5^{\circ} 03^{\prime} \mathrm{E}$ & 5 & 22 & $18 \mathrm{Jul} 2008$ & mixed culture obtained in $\mathrm{PRO} 2 / 5$ & MAD \\
\hline
\end{tabular}

${ }^{a}$ Isolates are identified by their RCC (Roscoff Culture Collection) numbers.

$\mathrm{b}$ Indicates the agar medium used to isolate the corresponding organism (see the Material and methods section). 
peptone (Difco), $0.1 \mathrm{~g}$ yeast extract (Difco), $\mathrm{NH}_{4} \mathrm{Cl}(10 \mu \mathrm{M})$, $\mathrm{KH}_{2} \mathrm{PO}_{4}(1 \mu \mathrm{M})$, nicotinic acid $(2 \mu \mathrm{M})$, biotin $\left(2.10^{-9} \mathrm{M}\right)$ vitamin $\mathrm{B}_{12}\left(4.10^{-10} \mathrm{M}\right), 1 \mathrm{ml}$ of $\mathrm{K}$ medium trace elements (Keller et al., 1987) and $15 \mathrm{~g}$ agar (Difco) per liter of seawater sampled offshore during the cruise. MiA medium was a modified version of the latter where peptone was omitted and local seawater was replaced by the supernatant of a culture of Isochrysis aff. galbana (RCC 179) freshly grown in K medium (Keller et al., 1987). After the cruise, AAP isolates were also obtained by streaking on MAD medium $3-5 \mu$ of microalgal or cyanobacterial cultures enriched onboard as previously described (Le Gall et al., 2008). Briefly, seawater sample was filtered by simple gravity through two superposed (in an effort to provide more tight size fractionation) Nuclepore filters of $47 \mathrm{~mm}$ diameter, with either $0.6 \mu \mathrm{m}$ or $3 \mu \mathrm{m}$ porosity (Whatman International Ltd, Maidstone, UK). The filtrate was partitioned into $50 \mathrm{ml}$ culture flasks (Sarstedt, Orsay, France) to which was added either 1/100 of full strength Jaworski medium (Jaworski et al., 1981) for photosynthetic eukaryotes or 1/5 of full strength Pro2 medium (Moore and Chisholm, 1999) for picocyanobacteria (Prochlorococcus and Synechococcus). In order to promote the growth of nitrate-assimilating cyanobacteria, the latter medium amended with $10 \mu \mathrm{M}$ nitrate was also used.

After incubation at $18^{\circ} \mathrm{C}$ for 7 days in the dark, MAD agar plates were transferred into thermostatic cabinets illuminated by luminescent tubes (Sylvania daylight $18 \mathrm{~W}$ ) at irradiance levels of $120 \mu \mathrm{mol}$ photons $\mathrm{m}^{-2} \mathrm{~s}^{-1}$ (for surface samples) and $25 \mu \mathrm{mol}$ photons $\mathrm{m}^{-2} \mathrm{~s}^{-1}$ (for DCM samples) in 12:12 light-dark cycle.

Detection of BChl- $a$-containing colonies was performed using a CCD camera based fluorescence imaging. Briefly, after up to $7-8$ weeks of incubation at $18^{\circ} \mathrm{C}$, colonies grown on the MA, MiA and MAD media were illuminated by a set of Nichia blue light emitting diodes $(470 \mathrm{~nm})$. Infra-red fluorescence from BChl- $a$-containing colonies was registered by a CCD camera (Photon Systems Instruments Ltd., Brno, Czechia) protected by a long pass $>850 \mathrm{~nm}$ glass filter (Oriel 51360 , USA). The purification procedure on MAD plates was repeated two to three times until cultures were considered pure. The presence of BChl- $a$ signal was evaluated using an infra-red kinetic fluorometer (model FL3500, Photon Systems Instruments Ltd.) in pure cultures cultivated in 1/10 marine broth under a $14 \mathrm{~h}-10 \mathrm{~h}$ light-dark regime.

For DNA extraction, cell pellets from $1.5-\mathrm{ml}$ cultures were suspended in MilliQ water, boiled for $10 \mathrm{~min}$, left at room temperature for $10 \mathrm{~min}$, boiled again for $10 \mathrm{~min}$ and centrifuged $\left(5000 \mathrm{~g}, 5 \mathrm{~min}, 4^{\circ} \mathrm{C}\right)$. The presence of $p u f M$ was determined by using PCR amplification with specific primers (Lehours et al., 2010).

Small-subunit rRNA genes were amplified by PCR using universal reverse primer 1492R (5'CGGTTACCTTGTTACGACTT-3') and Bacteria-specific primer $8 \mathrm{~F}\left(5^{\prime}\right.$-AGAGTTTGATYMTGGCTCAG-3'). Reaction mixtures $(25 \mu \mathrm{l})$ contained the following components:
$5 \mathrm{X}$ buffer $(5 \mu \mathrm{l}), 2 \mathrm{mM} \mathrm{MgCl}_{2}, 10$ pmoles of each deoxyribonucleotide triphosphate (dATP, dCTP, dGTP, dTTP; Eurogentec), 10 pmoles of each oligonucleotide primer, 1.25 U of GoTaq Flexi DNA polymerase (Promega, Madison, USA) and $1 \mu \mathrm{l}$ of extract. The initial denaturation step consisted of heating the reaction mixture at $95^{\circ} \mathrm{C}$ for $10 \mathrm{~min}$, and the thermal profile then consisted of 30 cycles of denaturation at $94^{\circ} \mathrm{C}$ for $1 \mathrm{~min}$, annealing at $50^{\circ} \mathrm{C}$ for $1 \mathrm{~min}$ and extension at $72^{\circ} \mathrm{C}$ for $1.5 \mathrm{~min}$. A final extension step was carried out at $72^{\circ} \mathrm{C}$ for $10 \mathrm{~min}$. The PCR products were grouped initially by restriction fragment length polymorphism (RFLP) using HaeIII and MnlI restriction patterns.

Amplified PCR products were purified using the ExoSap purification kit (ExoSap-it, GE Healthcare, Uppsala, Sweden). 16S rRNA gene sequences of at least two randomly chosen strains from each RFLP group (if applicable) were sequenced using an ABI 3130 POP7 sequencer (Applied Biosystems) at the Biogenouest Sequencing-Genotyping Platform (Roscoff site).

\subsection{RNA isolation}

Total RNA was extracted using a NucleoSpin RNA II isolation kit (Macherey-Nagel), with several modifications to recover RNA possibly released to the $1 \mathrm{ml}$ RNAlater due to the sample freeze and thaw (Frias-Lopez et al., 2008). Samples were thawed on ice, and the $1 \mathrm{ml}$ of RNAlater was loaded on a Microcon YM-50 column (Millipore, Billerica, USA) for desalting and concentrating by centrifugal filtration. The resulting $50 \mu \mathrm{l}$ of RNAlater were added back to the sample tubes containing $50 \mu \mathrm{l}$ of glass beads $(100 \mu \mathrm{m})$ and $350 \mu \mathrm{l}$ of RA1 buffer, and total RNA extraction was performed following the NucleoSpin RNA II manual. Genomic DNA was removed using a Turbo DNA-free kit (Ambion). DNA removal in RNA samples was confirmed by control PCR amplifications that contained RNA and were not previously subjected to the reverse transcription step. No amplification was detected in these controls performed following the PCR conditions described below.

\subsection{Reverse transcription and cDNA amplification}

ThermoScript RT-PCR system (Invitrogen, Carlsbad, USA) was used for the reverse transcription of pufM mRNA from total RNA samples isolated from stations A, 21, 1 and C. All reverse transcription reactions were performed in a total reaction volume of $10 \mu \mathrm{l}$. cDNA synthesis was performed at $55^{\circ} \mathrm{C}$ using the PufWAW reverse primer $\left(5^{\prime}\right.$ AYNGCRAACCACCANGCCCA-3', Yutin et al., 2005) as gene-specific primer. On the basis of specificity and efficiency (e.g. yield) results (Lehours et al., 2010), we selected PufMF forward (5'-TACGGSAACCTGTWCTAC-3', Béjà et al., 2002) and PufWAW reverse primers to amplify pufM genes in cDNA samples. Reaction mixtures $(25 \mu \mathrm{l})$ prepared 
as previously contained 1 to $3 \mu \mathrm{l}$ of cDNA sample. Amplifications were carried out in a GeneAmp PCR system 9700 (Applied Biosystems, Foster City, USA) with the following parameters: $95^{\circ} \mathrm{C}$ for $5 \mathrm{~min}$, followed by 35 cycles of $95^{\circ} \mathrm{C}$ for $30 \mathrm{~s}, 58^{\circ} \mathrm{C}$ for $30 \mathrm{~s}$, and $72^{\circ} \mathrm{C}$ for $30 \mathrm{~s}$, with a final extension step at $72^{\circ} \mathrm{C}$ for $10 \mathrm{~min}$. PCR products were loaded in a $0.8 \%$ agarose gel containing $0.5 \mu \mathrm{g} \mathrm{ml}^{-1}$ ethidium bromide, and electrophoresed at $80 \mathrm{~V}$ for $1.5 \mathrm{~h}$. Since the amplified DNA was later released from gel for the cloning procedure, modified Tris-acetate EDTA (TAE) buffer (1 mM NaEDTA (pH 8.0), $40 \mathrm{mM}$ Tris acetate) was used to prepare the agarose gel and as the running buffer. The DNA band of the targeted size was carefully cut from the gel using a transilluminator and DNA isolated from gel using an UltrafreeDA centrifuge filter (Millipore).

\subsection{Library construction and analyses}

Fresh RT-PCR products were cloned using the TOPO-TA cloning kit according to the manufacturer's instructions (Invitrogen). Recombinant clones were screened for insertcontaining plasmids by direct PCR amplification with M13 forward and reverse primers. Clones were sequenced using the latter primers at the Biogenouest Sequencing-Genotyping Platform (Roscoff site). Clone libraries were screened for chimeric sequences with Chimera_Check program available on the RDP website (Cole et al., 2003). The remaining sequences were subjected to BLAST search against publicly available sequences to determine their approximate phylogenetic affiliations. A conservative value of $94 \%$ nucleic acid sequence similarity (Zeng et al., 2007) was chosen for grouping sequences into Operational Taxonomic Units (OTUs) using Mothur (Schloss et al., 2009). Coverage value (C) was calculated as previously described (Mullins et al., 1995).

\subsection{Phylogenetic analyses}

Sequence data were analyzed with the ARB software package (Ludwig et al., 2004). The new sequences were added to the SSU ARB database and aligned with the Fast Aligner tool. Alignments were checked and corrected manually where necessary. 16S rRNA gene sequences from the isolates were compared to sequences in public databases with BLASTn (Altschul et al., 1997). 16S rRNA gene sequences with high similarities to those determined in this study were retrieved and added to the alignment. Framework trees were calculated with fastDNAmL, a maximum-likelihood method implemented in ARB, using only almost full-length sequences. The stability of the branching pattern was tested with the neighbor-joining and maximum parsimony (DNAPARS) methods included in the PHYLIP package as implemented in ARB.

A pufM database containing more than 700 aligned sequences of cultured species and environmental clones retrieved from GenBank database (http://www.ncbi.nlm.nih.
gov/Genbank) and the GOS scaffold nucleotide sequences was constructed using ARB (Ludwig et al., 2004). Sequences were translated to protein and the resulting alignment was then used to manually realign nucleotide sequences. A neighbor-joining tree was first constructed with all the sequences longer than $600 \mathrm{bp}$ and the robustness of inferred tree topologies was tested by bootstrap analysis (1000 resamplings) using PHYLIP (Felsenstein, 1993). Shorter sequences were aligned as above and added to the tree using ADD-BY-PARSIMONY algorithm, which allows the addition of short sequences to existing phylogenetic trees without changing global tree topologies. Phylogenetic tree display and annotation were performed with iTOL software (Letunic and Bork, 2007).

\subsection{Nucleotide sequence accession numbers}

The 16S rRNA and environmental pufM gene sequences obtained in this study are available in GenBank database under the accession numbers HQ871842-HQ871863 and JF421730-JF421749, respectively. The $p u f M$ gene sequences of the isolates have been deposited in EMBL database under the accession numbers FR852756-FR852767.

\section{Results}

\subsection{Oceanographic context}

The oceanographic context, the physical and hydrologic characteristics of the water masses in the Mediterranean Sea during BOUM cruise are extensively described by Moutin et al. (2011). Briefly, sea surface temperatures ranged from $21.4^{\circ} \mathrm{C}$ (station 25 in the western basin) to $26.9^{\circ} \mathrm{C}$ (station B in the eastern basin). Salinity was higher in the eastern basin and especially from station 5 where it remained above $39 \%$ down to $200 \mathrm{~m}$ depth. Nutrient concentrations were close or below the detection limit in the upper layers, decreased in the eastern basin where lower pigment concentrations and primary production rates were measured (Pujo-Pay et al., 2011). Chlorophyll concentration showed a well defined Deep Chlorophyll Maximum (DCM), more pronounced in the western basin (for details, see Crombet et al., 2011), and deepening from west ( $\sim 40$ to $80 \mathrm{~m}$ ) to east (from 80 to $>100 \mathrm{~m}$ ).

\subsection{AAP isolates}

Colonies grown on the agar plates of the three media used in this study were screened for the presence of BChl- $a$. The numbers of colonies showing infra-red fluorescence under blue light illumination varied greatly between samples. AAP bacteria represented only a small percentage (less than $1 \%$ ) of the cultivable bacterial community. A total of 54 AAP strains were isolated; 38 strains were obtained after direct plating of the fresh seawater samples and 16 were retrieved 
Table 2. Closest phylogenetic neighbor, nucleotide accession number and 16S rRNA gene sequence length of the AAP bacteria isolated from the Mediterranean Sea.

\begin{tabular}{|c|c|c|c|c|}
\hline Isolate & $\begin{array}{l}\text { 16S rRNA } \\
\text { sequence } \\
\text { length (bp) }\end{array}$ & $\begin{array}{c}\text { Nucleotide } \\
\text { accession } \\
\text { no. }\end{array}$ & $\begin{array}{l}\text { Closest described species } \\
(\% \text { 16S rRNA sequence identity })^{*}\end{array}$ & Other strains with identical RFLP \\
\hline RCC 1876 & 1274 & HQ871842 & Erythrobacter litoralis (98) & \\
\hline RCC 1877 & 1317 & HQ871843 & Erythrobacter litoralis (98) & \\
\hline RCC 1878 & 1315 & HQ871844 & Citromicrobium bathyomarinum (99) & 19 (RCC 1879-87, RCC 1890-98, RCC1907) \\
\hline RCC 1888 & 1318 & HQ871846 & Sulfitobacter dubius (96) & \\
\hline RCC 1889 & 1352 & HQ871847 & Erythobacter aquamaris (99) & 5 (RCC 1899-04) \\
\hline RCC 1906 & 1300 & HQ871851 & Sagittula stellata (96) & $1(\mathrm{RCC} 1923)$ \\
\hline RCC 1908 & 1272 & HQ871852 & Thalassobaculum salexigens (94) & $1(\mathrm{RCC} 1918)$ \\
\hline RCC 1909 & 1072 & HQ871853 & Tateyamaria omphalii (98) & \\
\hline RCC 1910 & 1349 & HQ871854 & Thalassobaculum litoreum (99) & \\
\hline RCC 1919 & 1351 & HQ871856 & Tateyamaria omphalii (97) & \\
\hline RCC 1920 & 1357 & HQ871857 & Marivita litorea (99) & \\
\hline RCC 1921 & 1361 & HQ871858 & Marivita cryptomonadis (98) & \\
\hline RCC 1922 & 1352 & HQ871859 & Roseovarius halotolerans (97) & 2 (RCC1924, RCC1929) \\
\hline RCC 1925 & 1381 & HQ871861 & Thalassobaculum salexigens (94) & 1 (RCC 1926) \\
\hline RCC 1927 & 1364 & HQ871862 & Roseibacterium elongatum (96) & \\
\hline RCC 1928 & 1367 & HQ871863 & Roseovarius tolerans (99) & 8 (RCC 1905, RCC 1911-17) \\
\hline
\end{tabular}

* As determined by the program BLAST.

after streaking of primary algal or cyanobacterial cultures enriched onboard from seawater samples (Table 1). All but one strains cultivated after direct plating were recovered on the two media with low nutrient and carbon content. Twenty four strains were isolated from the western basin (4 stations), 13 from the central basin ( 3 stations) and one from the eastern basin (1 station). All isolates were positive for the presence of the pufM gene by PCR amplification. BChl- $a$ fluorescence signals were detected in the cultures of all isolates when grown in 1/10 marine broth.

Phylogenetic analysis of $16 \mathrm{~S}$ rRNA and pufM gene sequences demonstrated that all isolates were exclusively alphaproteobacterial and were more closely related to members of the Alpha-1, Alpha-3 and Alpha-4-proteobacteria (Table 2, Figs. 2 and 3a). Twenty isolates recovered from surface or DCM waters were almost identical ( $\sim 99.8 \% 16 \mathrm{~S}$ rRNA identity) to Citromicrobium bathyomarinum. Within the Alpha-4-proteobacteria, two other clusters representing 8 strains were affiliated to Erythrobacter species (>98\%). Among the most frequently isolated strains, twelve belonged to the genus Roseovarius. Interestingly, all strains having $R$. tolerans as closest cultivated species $(98 \%)$ were isolated after direct plating of seawater samples whereas those affiliated to $R$. halotolerans were obtained from microalgal cultures. A portion of the isolates was highly related to recently described genera, whose species were not known to synthesize BChl- $a$. Among them, RCC 1920 and RCC 1921 represented two strains of the recently described genus Marivita and had $M$. litoreum and $M$. cryptomonadis as closest cultivated neighbors (>98\%), respectively. Although pufL and pufM genes were amplified from the type strains of both Marivita species, production of BChl- $a$ was not detected in their cultures (Hwang et al., 2009). Two isolates (RCC 1909 and RCC 1919) were identified as very close relatives of Tateyamaria omphalii (97-98\%). In the genus Tateyamaria, BChl$a$ has been detected only in the cells of T. pelophila (Kurahashi and Yokota, 2007; Sass et al., 2010). Within the Alpha1-proteobacteria, RCC 1910 was highly related (99\%) to Thalassobaculum litoreum while four strains (RCC 1908, RCC 1918, RCC 1925 and RCC 1926) were more distantly related to Thalassobaculum salexigens (94\%). Both species of the recently described genus Thalassobaculum were not reported to produce BChl- $a$ (Zhang et al., 2008; Urios et al., 2010).

Additionally to strains RCC 1908, RCC 1918, RCC 1925 and RCC 1926 that exhibited marked novelty (Table 2), other strains bearing $96 \%$ or less 16 rRNA gene sequence identity to taxonomically characterized species may also represent new taxa (Stackebrandt and Goebel, 1994). Among them was categorized strain RCC 1927 most closely related to Roseibacterium elongatum. Strains RCC 1906 and RCC 1923 may represent a new species of the genus Sagittula. S. stellata, the only species of this genus, was not reported to synthetize BChl-a (Gonzalez et al., 1997). Finally, we detected BChl- $a$ production in strain RCC1888 that had Sulfitobacter dubius as closest characterized relative. This phenotypic trait has been reported only in a few described Sulfitobacter species (Labrenz et al., 2000; Park et al., 2007; Yoon et al., 2007). 


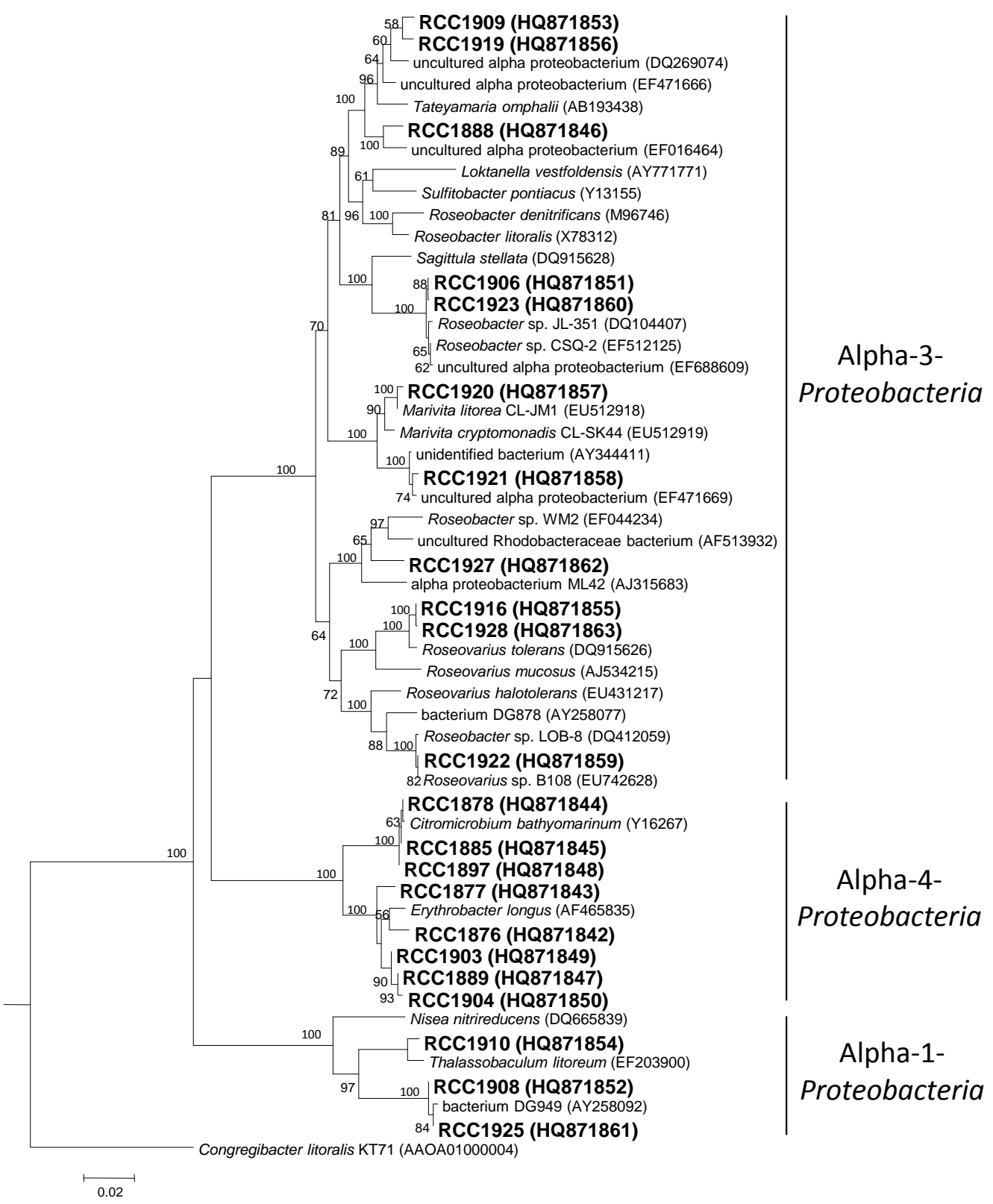

Fig. 2. Phylogenetic analysis based on the $16 \mathrm{~S}$ rRNA sequences indicating the position of selected AAP strains isolated during the BOUM cruise. The tree was calculated by the neighbor-joining method. Percentages of 1000 bootstrap resamplings that support branching points above $50 \%$ are indicated. Bar represents the number of substitutions per 100 sequence positions.

Most pufM gene sequences of the isolates did not cluster with that of cultivated organisms (Fig. 3a). They exhibited generally highest sequence levels of identity to sequences recovered from environments other than the Mediterranean Sea.

\subsection{Diversity of active AAP bacteria}

Functional expression of pufM mRNA transcripts, using reverse transcription-PCR to produce cDNA, was performed to determine which phylotypes were actively transcribing $p$ ufM in the Mediterranean Sea. We amplified by PCR pufM transcripts directly from RNA (cDNA) extracted from mixed picoplankton assemblages collected in the western and eastern Mediterranean Sea. Interestingly, pufM genes were amplified from samples collected during night time but no amplification products were obtained from those retrieved during the day (stations 25 and B). A total of 207 randomly picked clones containing pufM inserts were sequenced; 109 were recovered from station A and 11 from station 21 in the western 


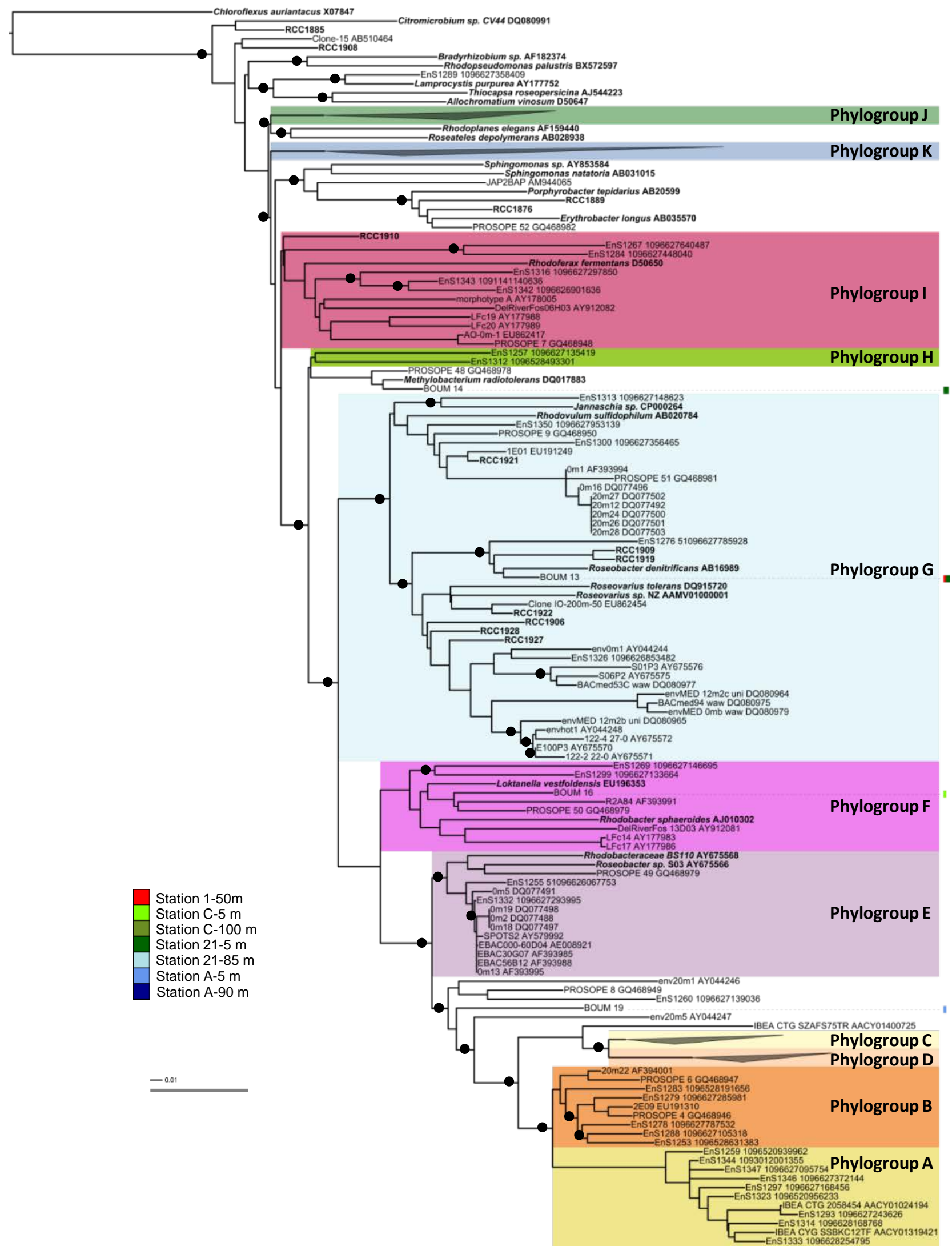

Fig. 3a. pufM phylogenetic trees showing the inferred phylogenetic relationships of pufM gene sequences from AAP isolates and environmental samples. Color ranges highlight the different groups defined by Yutin et al. (2007). (a) Phylogenetic relationships of pufM genes affiliated to phylogroups F, G, I and to unidentified phylogroups. 


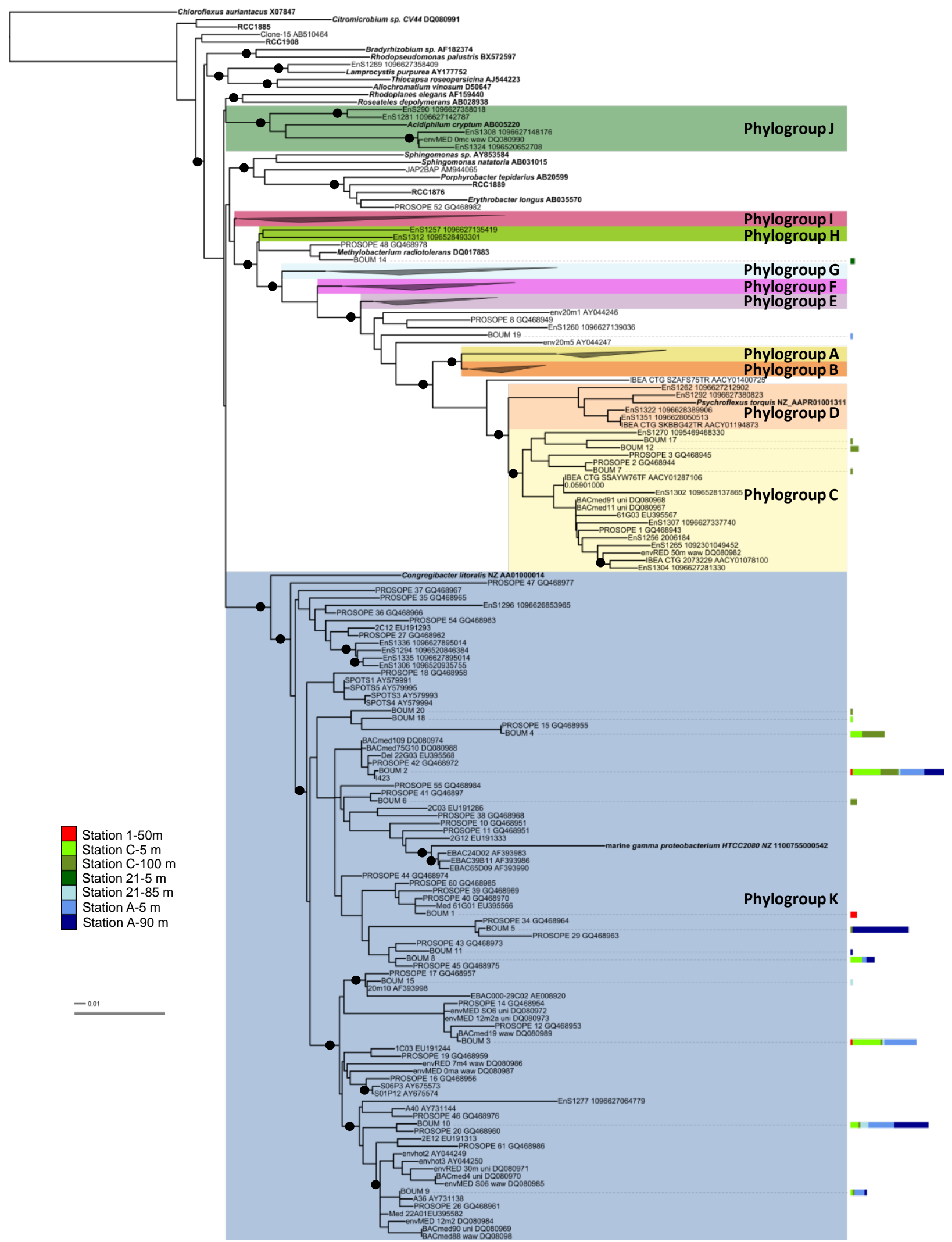

Fig. 3b. (b) Phylogenetic relationships of pufM genes affiliated to phylogroups $\mathrm{C}$ and $\mathrm{K}$ and to unidentified phylogroups. Trees are based on a neighbor-joining (NJ) tree to which short sequences were added by ARB_PARISMONY. Sequences used to construct NJ trees are marked in bold and black circles on nodes represent confidence values $>50 \%$ for branches found in the initial NJ trees. Sequences retrieved in this study are indicated as BOUM 1 to BOUM 20. The multivalue bar charts represent the relative frequencies of the corresponding OTU in the different clone libraries. Colors used to represent the clone libraries are indicated at the left of the trees. 
basin whereas 83 were retrieved from station $\mathrm{C}$ and 4 from station 1 in the eastern basin.

Using an operational taxonomic unit definition of $94 \%$ nucleic acid sequence similarity, 20 distinct OTUs were identified (Table 3 ). Coverage values $(>85 \%)$ indicated that most of the diversity was detected in the libraries. Most pufM sequences were more than $94 \%$ identical to known sequences and were related to clones retrieved from the Mediterranean Sea $(93.7 \%)$ (Table 3). None were closely related to that of our AAP isolates. The phylogenetic analysis demonstrated that the expressed $p u f M$ sequences were distributed into 4 of the 12 phylogroups previously defined by Yutin et al. (2007) (Fig. 3a and b). The diversity of pufM transcripts was higher at station $\mathrm{C}$ (Shannon-Wiener index $\mathrm{H}^{\prime}=2.1$ ), located in the most oligotrophic region of the Mediterranean Sea, than at station $\mathrm{A}\left(\mathrm{H}^{\prime}=1.6\right)$.

Only two OTUs, namely BOUM 13 (3 sequences) and BOUM 14 (2 sequences) were most similar to sequences of known organisms, Roseobacter denitrificans and Methylobacterium radiotolerans, respectively. Thirteen OTUs, representing $94 \%$ of the sequences, fell into group K which contained Gammaproteobacteria representatives including few isolates such as Congregibacter litoralis KT71 (Eilers et al., 2001), strains NOR5-3, NOR51B and HTCC2080 (Cho et al., 2007) and BAC clones EBAC65D09 and EBAC29C02 (Béjà et al., 2002), all related to the NOR5/OM60 clade (Rappe et al., 1997). Most of them were very highly similar $(\geq 97 \%)$ to sequences recovered from the Mediterranean Sea (Lehours et al., 2010). The most dominant gammaproteobacterial OTUs (i.e. OTUs BOUM $2,-3$ and -10 ) were recovered in both basins. BOUM 2 and BOUM 10 were uniformly distributed along the euphotic layer while BOUM 3 predominated in surface samples. BOUM 4, representing more than $20 \%$ of the sequences at station $\mathrm{C}$, was absent in other stations. In contrast, BOUM 5 only detected in DCM samples predominated at station A.

\section{Discussion}

The BOUM cruise constituted a unique opportunity for ecological studies as it offered a large range of trophic conditions from the ultra-oligotrophic eastern basin to the less oligotrophic western basin during the stratification period. A parallel study carried out during the same cruise reported the largest spatial dataset of BChl- $a$ concentrations in the Mediterranean Sea and provided a comprehensive picture of biogeographical trends of AAP bacteria along its different trophic regimes (Lamy et al., 2011). To complement these detailed data on their abundance and distribution, we aimed in this study at identifying the diversity and distribution of cultivable and metabolically active AAP bacteria along the two major basins of the Mediterranean Sea.

\subsection{Dominance of Alphaproteobacteria in the cultivable community}

Our data report a decrease of the numbers of AAP colonies from the western to the eastern basin of the Mediterranean Sea. This is in agreement with the HPLC and infrared microscopy data of Lamy et al. (2011) revealing the decrease of BChl- $a$ concentrations and AAP bacterial abundance from west to east. All BChl- $a$-containing bacteria that formed visible colonies on plates were identified phylogenetically, thus assessing cultivable diversity although AAP bacteria represented a low part of the cultivable fraction. To our knowledge, although several studies examined the cultivable diversity of marine AAP bacteria (Allgaier et al., 2003; Koblizek et al., 2003; Rathgeber et al., 2008; Salka et al., 2008), this work presents the largest collection of AAP bacteria isolated in the frame of an oceanographic cruise. All our isolates belonged to the Alphaproteobacteria. This finding is not very surprising because AAP bacteria are dispersed throughout the Alphaproteobacteria, with one known betaproteobacterial representative, Roseateles depolymerans (Suyama et al., 1999), one described gammaproteobacterial species, Congregibacter litoralis (Eilers et al., 2001; Fuchs et al., 2007) and three unassigned gammaproteobacterial isolates (Cho and Giovannoni, 2004; Cho et al., 2007; Thrash et al., 2010).

The distribution of our isolates within at least 9 different genera reflects a high cultivable diversity for this functional group in the Mediterranean Sea. The most frequent AAP isolate was $C$. bathyomarinum, originally isolated from deepsea hydrothermal vent plume waters (Yurkov and Beatty, 1998a). Other strains of $C$. bathyomarinum were isolated from deep ocean waters above the Juan de Fuca Ridge in the Pacific Ocean (Rathgeber et al., 2008). Since these authors were unsuccessful to obtain colonies of $C$. bathyomarinum offset from hydrothermal vents, they suggest that it may be endemic to deep vent plumes and possibly benefit from hydrothermal effluent components. However, the wide distribution of $C$. bathyomarinum in the upper waters of the Mediterranean Sea (3 stations within the western basin and the Ionian Sea at the surface and up to $85 \mathrm{~m}$ depth) and their occurrence in other surface marine waters (Koblizek et al., 2003; Jiao et al., 2010) does not favor this hypothesis. The frequent isolation of Erythrobacter species is not surprising since Erythrobacter spp. are among the more commonly cultured BChl- $a$-containing bacteria recovered from marine environments (Shiba et al., 1991; Kolber et al., 2001; Koblizek et al., 2003) .

Several of our isolates belonged to species whose type strains were not reported to produce BChl- $a$. It is even not uncommon that strains containing the pufL and pufM genes were found not to produce BChl- $a$ (Allgaier et al., 2003; Park et al., 2007; Hwang et al., 2009), pointing out that the expression of the photosynthetic reaction centre genes seems to be highly dependent on environmental parameters. These failures may probably be considered as a 
Table 3. Phylogenetic affiliation and accession numbers of operational taxonomic units (OTU) recovered in the RNA-based pufM libraries and general features of their closest relatives in GenBank

\begin{tabular}{|c|c|c|c|c|c|c|c|}
\hline OTU & Representative clone & $\begin{array}{l}\text { Accession } \\
\text { number }\end{array}$ & $\begin{array}{l}\text { Phylogenetic } \\
\text { affiliation }\end{array}$ & Closest relative in GenBank & $\begin{array}{l}\text { Identity } \\
(\%)\end{array}$ & Habitat of closest relative & $\begin{array}{c}\text { Accession } \\
\text { number }\end{array}$ \\
\hline BOUM 1 & BOUM StC7-P236 & JF421730 & $\gamma$-Proteobacteria & Uncultured bacterium clone PROSOPE 40 & 98 & Mediterranean Sea & GQ468970 \\
\hline BOUM 2 & BOUM_StC7-P349 & JF421731 & $\gamma$-Proteobacteria & Uncultured bacterium clone PROSOPE 42 & 99 & Mediterranean Sea & GQ468972 \\
\hline BOUM 3 & BOUM StA6-CJ7 & JF421732 & $\gamma$-Proteobacteria & Uncultured bacterium clone PROSOPE 14 & 99 & Mediterranean Sea & GQ468954 \\
\hline BOUM 4 & BOUM StC3-CJ3 & JF421733 & $\gamma$-Proteobacteria & Uncultured bacterium clone PROSOPE 15 & 100 & Mediterranean Sea & GQ468955 \\
\hline BOUM 5 & BOUM StA2-P128 & JF421734 & $\gamma$-Proteobacteria & Uncultured bacterium clone PROSOPE 34 & 99 & Mediterranean Sea & GQ468964 \\
\hline BOUM 6 & BOUM StC3-P114 & JF421735 & $\gamma$-Proteobacteria & Uncultured bacterium clone PROSOPE 41 & 97 & Mediterranean Sea & GQ468971 \\
\hline BOUM 7 & BOUM StC3-CJ17 & JF421736 & Unresolved & Uncultured bacterium clone PROSOPE 2 & 99 & Mediterranean Sea & GQ468944 \\
\hline BOUM 8 & BOUM StA6-P175 & JF421737 & $\gamma$-Proteobacteria & Uncultured bacterium clone PROSOPE 45 & 97 & Mediterranean Sea & GQ468975 \\
\hline BOUM 9 & BOUM StA6-CJ24 & JF421738 & $\gamma$-Proteobacteria & Uncultured bacterium clone PROSOPE 26 & 98 & Mediterranean Sea & GQ468961 \\
\hline BOUM 10 & BOUM St213-P260 & JF421739 & $\gamma$-Proteobacteria & Uncultured bacterium clone PROSOPE 20 & 97 & Mediterranean Sea & GQ468960 \\
\hline BOUM 11 & BOUM StA2-P146 & JF421740 & $\gamma$-Proteobacteria & Uncultured bacterium clone $2 \mathrm{~A} 08$ & 96 & Delaware Bay & EU191269 \\
\hline BOUM 12 & BOUM StC3-P18 & JF421741 & Unresolved & Uncultured bacterium clone envSargasso & 87 & Sargasso sea & DQ080981 \\
\hline BOUM 13 & BOUM St216-P381 & JF421742 & $\alpha$-Proteobacteria & Roseobacter denitrificans OCh114 & 98 & $\begin{array}{l}\text { Coastal marine sediments } \\
\text { (Australia) }\end{array}$ & $\mathrm{CP} 000362$ \\
\hline BOUM 14 & BOUM St216-P280 & JF421743 & $\alpha$-Proteobacteria & Methylobacterium radiotolerans JCM2831 & 95 & Japanese unhulled rice & CP001002 \\
\hline BOUM 15 & BOUM St213-P354 & JF421744 & $\gamma$-Proteobacteria & Uncultured proteobacterium clone EBAC000-29C02 & 97 & Monterey Bay & AE008920 \\
\hline BOUM 16 & BOUM StC7-CJ19 & JF421745 & $\alpha$-Proteobacteria & Uncultured bacterium clone PROSOPE 50 & 86 & Mediterranean Sea & GQ468980 \\
\hline BOUM 17 & BOUM StC3-P336 & JF421746 & Unresolved & Global Ocean Sampling GS-31-01-01-1P3 & 90 & $\begin{array}{l}\text { Pacific Ocean } \\
\text { (Galapagos islands) }\end{array}$ & EK382594 \\
\hline BOUM 18 & BOUM StC7-P232 & JF421747 & $\gamma$-Proteobacteria & Uncultured bacterium clone $2 \mathrm{~A} 08$ & 88 & Delaware Bay & EU191269 \\
\hline BOUM 19 & BOUM StA6-P161 & JF421748 & Unresolved & Uncultured bacterium clone jl-npgw26-s7 & 95 & China Sea & AY652833 \\
\hline BOUM 20 & BOUM StC3-CJ10 & JF421749 & $\gamma$-Proteobacteria & Uncultured bacterium clone PROSOPE 45 & 93 & Mediterranean Sea & GQ468975 \\
\hline
\end{tabular}

result of inappropriate culture conditions employed (Biebl and Wagner-Dobler, 2006) and possibly inadequate methods to detect trace amounts of BChl- $a$ synthetized. In this study, we cultivated our strains in low carbon media under natural light-dark cycle and several independent lines of evidence indicate that all our isolates are AAPs. The pufM gene was amplified from all strains and BChl- $a$ signals and fluorescence were recorded in all cultures using fluorometry and infrared imaging, respectively. Species of the genus Roseovarius are among those whose cultures are reported to contain low amounts of BChl- $a$ and to show a strain-dependent BChl- $a$ production (Labrenz et al., 1999; Allgaier et al., 2003; Biebl et al., 2005a). Twelve Roseovarius strains representing two clades were identified. Although strains from both clades were recovered from the same sample, those related to $R$. halotolerans were only isolated from microalgal cultures obtained during the cruise. Similarly to $R$. mucosus (Biebl et al., 2005a) and other AAP bacteria isolated from algal cultures (Biebl et al., 2005b, 2006, 2007), this species may probably benefit from algal extracellular products. It is also conceivable that culture conditions used for algae may also contribute to the in vitro development of communities dominated by specific bacterial taxa. On the other hand, phytoplankton cultures are likely to select for different associated bacterial species that may rely on organic compounds available in algal exudates and production of osmolytes such as dimethylsulphoniopropionate (DMSP). It is, however, not possible to conclude whether algal growth and culture conditions selected for $R$. halotolerans-like bacteria, enhanced their growth or promoted their cultivability or ability to form colonies on agar medium. The high incidence of $R$. halo- tolerans-like bacteria associated with algal cultures did not appear to be restricted to this putative new species. Indeed, this culture approach allowed the isolation of three taxa - including an additional new species - that were not obtained by direct plating. Therefore, this study demonstrates that primary cocultivation with other organism(s) may be a fruitful approach to extend the cultivable diversity and to isolate previously uncultured microorganisms.

\subsection{Dominance of Gammaproteobacteria in the metabolically active AAP community}

The isolation and analysis of mRNA transcripts from environmental microbial samples is an important step to increase our understanding of the complex processes of microbial ecology. In order to investigate the diversity of bacteria expressing $p u f M$ mRNA at the time of sample collection and thus likely the photosynthetically active members of the AAP community, RT-PCR was performed to detect the expression of this gene coding for the photosynthetic reaction center. Our results showed that pufM transcripts could be detected from $\sim 11$ of seawater in all stations sampled during the night time. Using the same experimental conditions and the same seawater volume, no pufM RT-PCR products could be obtained from stations 25 and B sampled during the day time. This finding is consistent with the decrease of puf transcripts in $R$. denitrificans cultures shifted from darkness to light (Nishimura et al., 1996) and the complete inhibition of BChl- $a$ synthesis by high levels of irradiance in cultivated AAP bacteria (Yurkov and Beatty, 1998b). Since we succeeded in amplifying other functional genes using the 
same RNA extracts in RT-PCRs, the failure to amplify pufM mRNAs in daytime seawater samples was likely to be a consequence of the low relative amounts of these transcripts in the total RNA extracts. However, we acknowledge that pufM transcripts may have been obtained from larger volumes of seawater.

RT-PCR analysis has been used to detect the expression of functional (i.e. nifH and $a m o A$ ) genes in the environment and several studies have compared the composition of DNA and RNA-based assemblages (Zani et al., 2000; Labrenz et al., 2010). The majority of expressed $p u f M$ sequences were similar to sequences recovered previously in DNA libraries from the PROSOPE cruise in the Mediterranean Sea (Lehours et al., 2010). Unfortunately, we were not able to amplify $p u f M$ mRNAs from the stations harvested in both cruises, making difficult the comparison between both data sets. However, comparison between stations $\mathrm{C}$ and MIO, both located in the eastern basin, indicated that fewer photosynthetic groups detectable by direct PCR of DNA could be shown to express pufM. A similar trend has been observed in other studies (Zani et al., 2000) including pufM expression analysis in lake Fryxell (Antarctica) (Karr et al., 2003). We found substantial overlap between our RNA library and the PROSOPE DNA library produced by Lehours et al. (2010), but also many cases in which a particular DNA or RNA sequence occurred alone. Phylotypes BOUM 3, -5 and -10, well represented in the DNA library (as PROSOPE 14, 34 and 20), are clearly present and, as indicated by the detection of their mRNA, are presumably photosynthetically active as well. In contrast, the most frequently detected phylotype in the pufM mRNA library, namely BOUM 2 was not abundantly recovered in the DNA library. The expressed pufM sequences also included OTUs (BOUM 12,-17 and -19), previously undetected in the Mediterranean Sea. These phylotypes may represent bacteria that are uncommon but metabolically highly active.

Previous studies have also revealed a high contribution of Gammaproteobacteria to AAP populations in various marine environments (Hu et al., 2006; Masin et al., 2006; Yutin et al., 2007) but their activity has only been poorly evaluated (Béjà et al., 2002). The data obtained in this work support the previous observations on the abundance of the gammaproteobacterial AAP bacteria in the Mediterranean Sea (Lehours et al., 2010) and suggest their dominant photosynthetic activity. Our sequences fall into the NOR5/OM60 clade also well represented in a metagenomic library from the eastern Mediterranean Sea waters (Feingersch et al., 2010). This clade was recently shown to have a cosmopolitan occurrence in the marine environment, with a clear preference for coastal waters (Yutin et al., 2007; Yan et al., 2009). We did not clearly observed this habitat preference in the Mediterranean Sea since equivalent proportions of $p u f M$ gammaproteobacterial sequences were detected in coastal and off shore regions (Lehours et al., 2010). However, we acknowledge that this discrepancy may be linked to the fact that relative clone library abundance does not necessarily reflect relative natu- ral abundance. Moreover, although the four strains isolated from marine surface waters KT71, HTCC2080, HTCC2246 and HTCC2148 were shown to contain puf LM genes (Fuchs et al., 2007; Cho et al., 2007), it cannot be taken for granted that all members of NOR5/OM60 clade are AAP bacteria.

The highest diversity of $p u f M$ transcripts was present in the most oligotrophic basin where abundance of AAP bacteria is the lowest during the stratification period (Lamy et al., 2011). These findings are consistent with the contrasting variation of abundance and diversity of AAP assemblages suggested previously by a large-scale survey analysis of their distribution patterns (Jiao et al., 2007). The most abundantly detected phylotypes occurred in the western and eastern Mediterranean basins. However, several photosynthetically active OTUs (BOUM 4, -6, and -7) were exclusively detected in the ultra-oligotrophic eastern basin confirming our previous study (Lehours et al., 2010). In a companion paper, Lamy et al. (2011) showed that the concentration of BChl- $a$ per cell in AAP bacterial communities was significantly higher in the eastern basin than in the western basin, suggesting that reliance on phototrophy varied along the oligotrophic gradient and that nutrient and/or carbon limitation favors BChl- $a$ synthesis. Our results together with this last study suggest that in the most extreme oligotrophic conditions, competition due to nutrient limitation may favor less abundant AAP bacteria with high substrate affinity and increased BChl- $a$ synthesis, resulting in higher species diversity.

In the latter metagenomic analysis, Feingersch et al. (2010) showed that strain HTCC 2080, one of the four gammaproteobacterial AAP bacteria currently isolated, recruited hits displaying only a $70 \%$ identity average. This highlights that none of the current genome sequences are good references for organisms living in the eastern Mediterranean Sea. We attempted in this study to vary culture conditions to isolate the largest AAP diversity. By using low concentrations of undefined substrates like peptone and yeast extract, local seawater or supernatant of an algal culture, we were unable to grow gammaproteobacterial AAP colonies although they were active at the time of sampling. In the Mediterranean Sea, most of the AAP bacteria $(<0.8 \mu \mathrm{m}$ fraction) (Lamy et al., 2011) are free-living, the common lifestyle of oligotrophic bacteria. It has been shown that obligately oligotrophic gammaproteobacterial AAP bacteria are not able to form colonies on agar upon their first isolation from seawater (Cho and Giovannoni, 2004). We experienced this situation during the cruise because bacterial and AAP cultivability decreased along the oligotrophic gradient. This can explain our failure, but only partly, because gammaproteobacterial AAP bacteria have been isolated on agar plates (Eilers et al., 2000; Csotonyi et al., 2008). Since cultures of $C$. litoralis grow optimally in microaerophilic conditions (Fuchs et al., 2007; Spring et al., 2009), strategies that attempt to favor colony formation below the air-solid interface could be more appropriate. However, strain EG19, a 
distant relative to $C$. litoralis, is an obligate aerobe (Csotonyi et al., 2008). Finally, we propose that further cultivation attempts to isolate yet these uncultured AAP bacteria could consider filtration (pore size, $<0.8 \mu \mathrm{m}$ ) of the inoculum to remove large, generally highly active, particle-associated bacteria and colony isolation in soft agar medium for bacteria unable to grow at the air-water interface.

\section{Conclusions}

The present data based on AAP culture isolation and $p u f M$ transcripts bring two major conclusions:

i. RT-PCR analysis to identify the active populations of AAP bacteria supports the previous observations on the dominant role of the gammaproteobacterial AAP bacteria in the Mediterranean Sea during the stratification period.

ii. most environmental sequences were not affiliated with any cultivated organisms.

These data highlight the existing gaps in the understanding of aerobic anoxygenic photosynthesis, especially in the Mediterranean Sea and likely globally and form the basis for culture-dependent investigations to isolate these yet uncultured groups of bacteria.

Acknowledgements. This is a contribution of the BOUM (Biogeochemistry from the Oligotrophic to the Ultraoligotrophic Mediterranean) experiment (http://www.com.univ-mrs.fr/BOUM/) of the french national LEFE-CYBER program, the european IP SESAME and the international IMBER project. The BOUM experiment was coordinated by the Institut National des Sciences de l'Univers (INSU) and managed by the Centre National de la Recherche Scientifique (CNRS). The authors thank the crew of the R/V L'Atalante for outstanding shipboard operation. Claudie Marec and Louis Prieur are warmly thanked for their efficient help in CTD rosette management and data processing.

We wish to thank Thierry Moutin for coordinating the BOUM cruise and inviting us onboard. We are grateful to Michal Koblizek for help with detection of AAP bacterial colonies using the infra-red system available in his laboratory, Morgan Perennou and Gwenn Tanguy (Biogenouest Sequencing Platform-FR2424Station Biologique) for help with sequencing and to Sébastien Henry (FR2424-Station Biologique) for the fresh grown Isochrysis cultures. This work was financially supported by the program LEFE-CYBER PANAME (CNRS-INSU). Dominique Boeuf and Océane Dahan are supported by grants from the Ministry of Higher Education and Research.

Edited by: T. Moutin

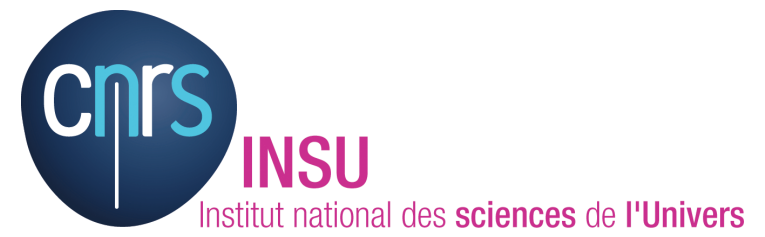

The publication of this article is financed by CNRS-INSU.

\section{References}

Allgaier, M., Uphoff, H., Felske, A., and Wagner-Dobler, I.: Aerobic anoxygenic photosynthesis in Roseobacter clade bacteria from diverse marine habitats, Appl. Environ. Microb., 69, 50515059, 2003.

Altschul, S. F., Madden, T. L., Schaffer, A. A., Zhang, J. H., Zhang, Z., Miller, W., and Lipman, D. J.: Gapped BLAST and PSIBLAST: a new generation of protein database search programs, Nucleic Acids Res., 25, 3389-3402, 1997.

Béjà, O., Suzuki, M. T., Heidelberg, J. F., Nelson, W. C., Preston, C. M., Hamada, T., Eisen, J. A., Fraser, C. M., and DeLong, E. F.: Unsuspected diversity among marine aerobic anoxygenic phototrophs, Nature, 415, 630-633, 2002.

Biebl, H. and Wagner-Dobler, I.: Growth and bacteriochlorophyll a formation in taxonomically diverse aerobic anoxygenic phototrophic bacteria in chemostat culture: Influence of light regimen and starvation, Process Biochem., 41, 2153-2159, 2006.

Biebl, H., Allgaier, M., Lunsdorf, H., Pukall, R., Tindall, B. J., and Wagner-Dobler, I.: Roseovarius mucosus sp. nov., a member of the Roseobacter clade with trace amounts of bacteriochlorophyll a, Int. J. Syst. Evol. Microbiol., 55, 2377-2383, 2005a.

Biebl, H., Allgaier, M., Tindall, B. J., Koblizek, M., Lunsdorf, H., Pukall, R., and Wagner-Dobler, I.: Dinoroseobacter shibae gen. nov., sp. nov., a new aerobic phototrophic bacterium isolated from dinoflagellates, Int. J. Syst. Evol. Micr., 55, 1089-1096, 2005b.

Biebl, H., Tindall, B. J., Pukall, R., Lunsdorf, H., Allgaier, M., and Wagner-Dobler, I.: Hoeflea phototrophica sp. nov., a novel marine aerobic alphaproteobacterium that forms bacteriochlorophyll a, Int. J. Syst. Evol. Micr., 56, 821-826, 2006.

Biebl, H., Pukall, R., Lunsdorf, H., Schulz, S., Allgaier, M., Tindall, B. J., and Wagner-Dobler, I.: Description of Labrenzia alexandrii gen. nov., sp. nov., a novel alphaproteobacterium containing bacteriochlorophyll a, and a proposal for reclassification of Stappia aggregata as Labrenzia aggregata comb. nov., of Stappia marina as Labrenzia marina comb. nov. and of Stappia alba as Labrenzia alba comb. nov., and emended descriptions of the genera Pannonibacter, Stappia and Roseibium, and of the species Roseibium denhamense and Roseibium hamelinense, Int. J. Syst. Evol. Micr., 57, 1095-1107, 2007.

Cho, J. C. and Giovannoni, S. J.: Cultivation and growth characteristics of a diverse group of oligotrophic marine Gammaproteobacteria, Appl. Environ. Microb., 70, 432-440, 2004.

Cho, J. C., Stapels, M. D., Morris, R. M., Vergin, K. L., Schwalbach, M. S., Givan, S. A., Barofsky, D. F., and Giovannoni, S. J.: Polyphyletic photosynthetic reaction centre genes in oligotrophic marine Gammaproteobacteria, Environ. Microbiol., 9, 1456-1463, 2007. 
Cole, J. R., Chai, B., Marsh, T. L., Farris, R. J., Wang, Q., Kulam, S. A., Chandra, S., McGarrell, D. M., Schmidt, T. M., Garrity, G. M., and Tiedje, J. M.: The Ribosomal Database Project (RDPII): previewing a new autoaligner that allows regular updates and the new prokaryotic taxonomy, Nucleic Acids Res., 31, 442-443, 2003.

Cottrell, M. T., Mannino, A., and Kirchman, D. L.: Aerobic anoxygenic phototrophic bacteria in the Mid-Atlantic Bight and the North Pacific Gyre, Appl. Environ. Microb., 72, 557-564, 2006.

Crombet, Y., Leblanc, K., Quéguiner, B., Moutin, T., Rimmelin, P., Ras, J., Claustre, H., Leblond, N., Oriol, L., and Pujo-Pay, M.: Deep silicon maxima in the stratified oligotrophic Mediterranean Sea, Biogeosciences, 8, 459-475, doi:10.5194/bg-8-4592011, 2011.

Csotonyi, J. T., Swiderski, J., Stackebrandt, E., and Yurkov, V. V.: Novel halophilic aerobic anoxygenic phototrophs from a Canadian hypersaline spring system, Extremophiles, 12, 529-539, 2008.

Eilers, H., Pernthaler, J., Glockner, F. O., and Amann, R.: Culturability and In situ abundance of pelagic bacteria from the North Sea, Appl. Environ. Microb., 66, 3044-3051, 2000.

Eilers, H., Pernthaler, J., Peplies, J., Glockner, F. O., Gerdts, G., and Amann, R.: Isolation of novel pelagic bacteria from the German bight and their seasonal contributions to surface picoplankton, Appl. Environ. Microb., 67, 5134-5142, 2001.

Feingersch, R., Suzuki, M. T., Shmoish, M., Sharon, I., Sabehi, G., Partensky, F., and Béjà, O.: Microbial community genomics in eastern Mediterranean Sea surface waters, ISME J., 4, 78-87, 2010.

Felsenstein, J.: PHYLIP (Phylogeny Inference Package). Version 3.5. , Department of Genetics, University of Washington, Seattle, 1993.

Frias-Lopez, J., Shi, Y., Tyson, G. W., Coleman, M. L., Schuster, S. C., Chisholm, S. W., and DeLong, E. F.: Microbial community gene expression in ocean surface waters, P. Natl. Acad. Sci. USA, 105, 3805-3810, 2008.

Fuchs, B. M., Spring, S., Teeling, H., Quast, C., Wulf, J., Schattenhofer, M., Yan, S., Ferriera, S., Johnson, J., Glockner, F. O., and Amann, R.: Characterization of a marine gammaproteobacterium capable of aerobic anoxygenic photosynthesis, P. Natl. Acad. Sci. USA, 104, 2891-2896, 2007.

Gonzalez, J. M., Mayer, F., Moran, M. A., Hodson, R. E., and Whitman, W. B.: Sagittula stellata gen. nov, sp. nov, a lignintransforming bacterium from a coastal environment, Int. J. Syst. Bacteriol., 47, 773-780, 1997.

$\mathrm{Hu}$, Y., Du, H., Jiao, N., and Zeng, Y.: Abundant presence of the gamma-like proteobacterial pufM gene in oxic seawater, FEMS Microbiol. Lett., 263, 200-206, 2006.

Hwang, C. Y., Bae, G. D., Yih, W., and Cho, B. C.: Marivita cryptomonadis gen. nov., sp. nov. and Marivita litorea sp. nov., of the family Rhodobacteraceae, isolated from marine habitats, Int. J. Syst. Evol. Micr., 59, 1568-1575, 2009.

Jaworski, G. H. M., Talling, J. F., and Heaney, S. I.: The influence of carbon dioxide-depletion on growth and sinking rate of 2 planktonic diatoms in culture, Br. Phycol. J., 16, 395-410, 1981.

Jiang, H., Dong, H., Yu, B., Lv, G., Deng, S., Wu, Y., Dai, M., and Jiao, N.: Abundance and diversity of aerobic anoxygenic phototrophic bacteria in saline lakes on the Tibetan plateau, FEMS Microbiol. Ecol., 67, 268-278, 2009.
Jiao, N., Zhang, Y., Zeng, Y., Hong, N., Liu, R., Chen, F., and Wang, P.: Distinct distribution pattern of abundance and diversity of aerobic anoxygenic phototrophic bacteria in the global ocean, Environ. Microbiol., 9, 3091-3099, 2007.

Jiao, N., Zhang, R., and Zheng, Q.: Coexistence of two different photosynthetic operons in Citromicrobium bathyomarinum JL354 as revealed by whole-genome sequencing, J. Bacteriol., 192, 1169-1170, 2010.

Karr, E. A., Sattley, W. M., Jung, D. O., Madigan, M. T., and Achenbach, L. A.: Remarkable diversity of phototrophic purple bacteria in a permanently frozen Antarctic lake, Appl. Environ. Microb., 69, 4910-4914, 2003.

Keller, M. D., Selvin, R. C., Claus, W., and Guillard, R. R. L.: Media for the culture of oceanic ultraphytoplankton, J. Phycol., 23, 633-638, 1987.

Koblizek, M., Béjà, O., Bidigare, R. R., Christensen, S., BenitezNelson, B., Vetriani, C., Kolber, M. K., Falkowski, P. G., and Kolber, Z. S.: Isolation and characterization of Erythrobacter sp. strains from the upper ocean, Arch. Microbiol., 180, 327-338, 2003.

Koblizek, M., Masin, M., Ras, J., Poulton, A. J., and Prasil, O.: Rapid growth rates of aerobic anoxygenic phototrophs in the ocean, Environ. Microbiol., 9, 2401-2406, 2007.

Kolber, Z. S., Van Dover, C. L., Niederman, R. A., and Falkowski, P. G.: Bacterial photosynthesis in surface waters of the open ocean, Nature, 407, 177-179, 2000.

Kolber, Z. S., Plumley, F. G., Lang, A. S., Beatty, J. T., Blankenship, R. E., VanDover, C. L., Vetriani, C., Koblizek, M., Rathgeber, C., and Falkowski, P. G.: Contribution of aerobic photoheterotrophic bacteria to the carbon cycle in the ocean, Science, 292, 2492 2495, 2001.

Kramer, J. G. and Singleton, F. L.: Variations in rRNA content of marine Vibrio spp during starvation-survival and recovery, Appl. Environ. Microb., 58, 201-207, 1992.

Kramer, J. G. and Singleton, F. L.: Measurement of rRNA variations in natural communities of microorganisms on the Southwestern U.S. continental shelf, Appl. Environ. Microb., 59, 2430-2436, 1993.

Kurahashi, M. and Yokota, A.: Tateyamaria omphalii gen. nov., sp. nov., an alpha-proteobacterium isolated from a top shell Omphalius pfeifferi pfeifferi, Syst. Appl. Microbiol., 30, 371-375, 2007.

Labrenz, M., Collins, M. D., Lawson, P. A., Tindall, B. J., Schumann, P., and Hirsch, P.: Roseovarius tolerans gen. nov., sp. nov., a budding bacterium with variable bacteriochlorophyll a production from hypersaline Ekho Lake, Int. J. Syst. Bacteriol., 49, 137-147, 1999.

Labrenz, M., Tindall, B. J., Lawson, P. A., Collins, M. D., Schumann, P., and Hirsch, P.: Staleya guttiformis gen. nov., sp. nov. and Sulfitobacter brevis sp. nov., alpha-3-Proteobacteria from hypersaline, heliothermal and meromictic antarctic Ekho Lake, Int. J. Syst. Evol. Micr., 50, 303-313, 2000.

Labrenz, M., Sintes, E., Toetzke, F., Zumsteg, A., Herndl, G. J., Seidler, M., and Jurgens, K.: Relevance of a crenarchaeotal subcluster related to Candidatus Nitrosopumilus maritimus to ammonia oxidation in the suboxic zone of the central Baltic Sea, ISME J., 4, 1496-1508, 2010.

Lamy, D., Jeanthon, C., Cottrell, M. T., Kirchman, D. L., Van Wambeke, F., Ras, J., Dahan, O., Pujo-Pay, M., Oriol, L., Bariat, L., Catala, P., Cornet-Barthaux, V., and Lebaron, P.: Ecology of 
aerobic anoxygenic phototrophic bacteria along an oligotrophic gradient in the Mediterranean Sea, Biogeosciences, 8, 973-985, doi:10.5194/bg-8-973-2011, 2011.

Le Gall, F., Rigaut-Jalabert, F., Marie, D., Garczarek, L., Viprey, M., Gobet, A., and Vaulot, D.: Picoplankton diversity in the South-East Pacific Ocean from cultures, Biogeosciences, 5, 203214, doi:10.5194/bg-5-203-2008, 2008.

Lehours, A. C., Cottrell, M. T., Dahan, O., Kirchman, D. L., and Jeanthon, C.: Summer distribution and diversity of aerobic anoxygenic phototrophic bacteria in the Mediterranean Sea in relation to environmental variables, FEMS Microbiol. Ecol., 74, 397-409, 2010.

Letunic, I. and Bork, P.: Interactive Tree Of Life (iTOL): an online tool for phylogenetic tree display and annotation, Bioinformatics, 23, 127-128, 2007.

Ludwig, W., Strunk, O., Westram, R., Richter, L., Meier, H., Yadhukumar, Buchner, A., Lai, T., Steppi, S., Jobb, G., Forster, W., Brettske, I., Gerber, S., Ginhart, A. W., Gross, O., Grumann, S., Hermann, S., Jost, R., Konig, A., Liss, T., Lussmann, R., May, M., Nonhoff, B., Reichel, B., Strehlow, R., Stamatakis, A., Stuckmann, N., Vilbig, A., Lenke, M., Ludwig, T., Bode, A., and Schleifer, K. H.: ARB: a software environment for sequence data, Nucleic Acids Res., 32, 1363-1371, 2004.

Martinez-Garcia, M., Diaz-Valdes, M., and Anton, J.: Diversity of pufM genes, involved in aerobic anoxygenic photosynthesis, in the bacterial communities associated with colonial ascidians, FEMS Microbiol. Ecol., 71, 387-398, 2010.

Masin, M., Zdun, A., Ston-Egiert, J., Nausch, M., Labrenz, M., Moulisova, V., and Koblızek, M.: Seasonal changes and diversity of aerobic anoxygenic phototrophs in the Baltic Sea, Aquat. Microb. Ecol., 45, 247-254, 2006.

Masin, M., Nedoma, J., Pechar, L., and Koblizek, M.: Distribution of aerobic anoxygenic phototrophs in temperate freshwater systems, Environ. Microbiol., 10, 1988-1996, 2008.

Moore, L. R. and Chisholm, S. W.: Photophysiology of the marine cyanobacterium Prochlorococcus: Ecotypic differences among cultured isolates, Limnol. Oceanogr., 44, 628-638, 1999.

Moutin, T., Van Wambeke, F., and Prieur, L.: Introduction to the Biogeochemistry from the Oligotrophic to the Ultraoligotrophic Mediterranean (BOUM) experiment, Biogeosciences, in preparation, 2011.

Mullins, T. D., Britschgi, T. B., Krest, R. L., and Giovannoni, S. J.: Genetic comparisons reveal the same unknown bacterial lineages in Atlantic and Pacific bacterioplankton communities, Limnol. Oceanogr., 40, 148-158, 1995.

Nishimura, K., Shimada, H., Ohta, H., Masuda, T., Shioi, Y., and Takamiya, K.: Expression of the puf operon in an aerobic photosynthetic bacterium, Roseobacter denitrificans, Plant Cell Physiol., 37, 153-159, 1996.

Oz, A., Sabehi, G., Koblizek, M., Massana, R., and Béjà, O.: Roseobacter-like bacteria in Red and Mediterranean Sea aerobic anoxygenic photosynthetic populations, Appl. Environ. Microbiol., 71, 344-353, 2005.

Park, J. R., Bae, J. W., Nam, Y. D., Chang, H. W., Kwon, H. Y., Quan, Z. X., and Park, Y. H.: Sulfitobacter litoralis sp. nov., a marine bacterium isolated from the East Sea, Korea, Int. J. Syst. Evol. Micr., 57, 692-695, 2007.

Pichard, S. L. and Paul, J. H.: Gene-expression per gene dose, a specific measure of gene-expression in aquatic microorganims,
Appl. Environ. Microb., 59, 451-457, 1993.

Pujo-Pay, M., Conan, P., Oriol, L., Cornet-Barthaux, V., Falco, C., Ghiglione, J.-F., Goyet, C., Moutin, T., and Prieur, L.: Integrated survey of elemental stoichiometry $(\mathrm{C}, \mathrm{N}, \mathrm{P})$ from the western to eastern Mediterranean Sea, Biogeosciences, 8, 883899, doi:10.5194/bg-8-883-2011, 2011.

Ranchou-Peyruse, A., Herbert, R., Caumette, P., and Guyoneaud, R.: Comparison of cultivation-dependent and molecular methods for studying the diversity of anoxygenic purple phototrophs in sediments of an eutrophic brackish lagoon, Environ. Microbiol., 8, 1590-1599, 2006.

Rappe, M. S., Kemp, P. F., and Giovannoni, S. J.: Phylogenetic diversity of marine coastal picoplankton $16 \mathrm{~S}$ rRNA genes cloned from the continental shelf off Cape Hatteras, North Carolina, Limnol. Oceanogr., 42, 811-826, 1997.

Rathgeber, C., Lince, M. T., Alric, J., Lang, A. S., Humphrey, E., Blankenship, R. E., Vermeglio, A., Plumley, F. G., Van Dover, C. L., Beatty, J. T., and Yurkov, V.: Vertical distribution and characterization of aerobic phototrophic bacteria at the Juan de Fuca Ridge in the Pacific Ocean, Photosynth. Res., 97, 235-244, 2008.

Salka, I., Moulisova, V., Koblizek, M., Jost, G., Jurgens, K., and Labrenz, M.: Abundance, depth distribution, and composition of aerobic bacteriochlorophyll a-producing bacteria in four basins of the central Baltic Sea, Appl. Environ. Microb., 74, 4398-4404, 2008.

Sass, H., Kopke, B., Rutters, H., Feuerlein, T., Droge, S., Cypionka, H., and Engelen, B.: Tateyamaria pelophila sp. nov., a facultatively anaerobic alphaproteobacterium isolated from tidal-flat sediment, and emended descriptions of the genus Tateyamaria and of Tateyamaria omphalii, Int. J. Syst. Evol. Micr., 60, 17701777, 2010.

Schloss, P. D., Westcott, S. L., Ryabin, T., Hall, J. R., Hartmann, M., Hollister, E. B., Lesniewski, R. A., Oakley, B. B., Parks, D. H., Robinson, C. J., Sahl, J. W., Stres, B., Thallinger, G. G., Van Horn, D. J., and Weber, C. F.: Introducing Mothur: Open-source, platform-independent, community-supported software for describing and comparing microbial communities, Appl. Environ. Microb., 75, 7537-7541, 2009.

Schwalbach, M. S. and Fuhrman, J. A.: Wide-ranging abundances of aerobic anoxygenic phototrophic bacteria in the world ocean revealed by epifluorescence microscopy and quantitative PCR, Limnol. Oceanogr., 50, 620-628, 2005.

Shiba, T., Shioi, Y., Takamiya, K., Sutton, D. C., and Wilkinson, C. R.: Distribution and physiology of aerobic bacteria containing bacteriochlorophyll a on the east and west coasts of Australia, Appl. Environ. Microb., 57, 295-300, 1991.

Sieracki, M. E., Gilg, I. C., Thier, E. C., Poulton, N. J., and Goericke, R.: Distribution of planktonic aerobic anoxygenic photoheterotrophic bacteria in the northwest Atlantic, Limnol. Oceanogr., 51, 38-46, 2006.

Spring, S., Lunsdorf, H., Fuchs, B. M., and Tindall, B. J.: The photosynthetic apparatus and its regulation in the aerobic gammaproteobacterium Congregibacter litoralis gen. nov., sp. nov., PLoS One, 4(3), e4866, doi:10.1371/journal.pone.0004866, 2009.

Stackebrandt, E. and Goebel, B. M.: A place for DNA-DNA reassociation and 16S rRNA sequence analysis in the present species definition in bacteriology, Int. J. Syst. Bacteriol., 44, 846-849, 1994.

Suyama, T., Shigematsu, T., Takaichi, S., Nodasaka, Y., Fujikawa, 
S., Hosoya, H., Tokiwa, Y., Kanagawa, T., and Hanada, S.: Roseateles depolymerans gen. nov., sp. nov., a new bacteriochlorophyll a-containing obligate aerobe belonging to the betasubclass of the Proteobacteria, Int. J. Syst. Bacteriol., 49, 449457, 1999.

Thrash, J. C., Cho, J. C., Ferriera, S., Johnson, J., Vergin, K. L., and Giovannoni, S. J.: Genome sequences of strains HTCC2148 and HTCC2080, belonging to the OM60/NOR5 clade of the Gammaproteobacteria, J. Bacteriol., 192, 3842-3843, 2010.

Urios, L., Michotey, V., Intertaglia, L., Lesongeur, F., and Lebaron, P.: Thalassobaculum salexigens $\mathrm{sp}$. nov., a new member of the family Rhodospirillaceae from the NW Mediterranean Sea, and emended description of the genus Thalassobaculum, Int. J. Syst. Evol. Micr., 60, 2507-2507, 2010.

Von Gabain, A., Belasco, J. G., Schottel, J. L., Chang, A. C. Y., and Cohen, S. N.: Decay of messenger-RNA in Escherichia coli: investigation of the fate of specific segments of transcripts, P. Natl. Acad. Sci. USA, 80, 653-657, 1983.

Yan, S., Fuchs, B. M., Lenk, S., Harder, J., Wulf, J., Jiao, N. Z., and Amann, R.: Biogeography and phylogeny of the NOR5/OM60 clade of Gammaproteobacteria, Syst. Appl. Microbiol., 32, 124139, 2009.

Yoon, J. H., Kang, S. J., Lee, M. H., and Oh, T. K.: Description of Sulfitobacter donghicola sp. nov., isolated from seawater of the East Sea in Korea, transfer of Staleya guttiformis Labrenz et al. 2000 to the genus Sulfitobacter as Sulfitobacter guttiformis comb. nov. and emended description of the genus Sulfitobacter, Int. J. Syst. Evol. Micr., 57, 1788-1792, 2007.

Yurkov, V. and Beatty, J. T.: Isolation of aerobic anoxygenic photosynthetic bacteria from black smoker plume waters of the Juan de Fuca ridge in the Pacific ocean, Appl. Environ. Microb., 64, 337-341, 1998a.
Yurkov, V. V. and Beatty, J. T.: Aerobic anoxygenic phototrophic bacteria, Microbiol. Mol. Biol. R., 62, 695-724, 1998 b.

Yutin, N., Suzuki, M. T., and Béjà, O.: Novel primers reveal wider diversity among marine aerobic anoxygenic phototrophs, Appl. Environ. Microb., 71, 8958-8962, 2005.

Yutin, N., Suzuki, M. T., Teeling, H., Weber, M., Venter, J. C., Rusch, D. B., and Béjà, O.: Assessing diversity and biogeography of aerobic anoxygenic phototrophic bacteria in surface waters of the Atlantic and Pacific Oceans using the Global Ocean Sampling expedition metagenomes, Environ. Microbiol., 9, 1464-1475, 2007.

Yutin, N., Beja, O., and Suzuki, M. T.: The use of denaturing gradient gel electrophoresis with fully degenerate $p u f M$ primers to monitor aerobic anoxygenic phototrophic assemblages, Limnol. Oceanogr.-Meth., 6, 427-440, 2008.

Zani, S., Mellon, M. T., Collier, J. L., and Zehr, J. P.: Expression of nifH genes in natural microbial assemblages in Lake George, New York, detected by reverse transcriptase PCR, Appl. Environ. Microbiol., 66, 3119-3124, 2000.

Zeng, Y. H., Chen, X. H., and Jiao, N. Z.: Genetic diversity assessment of anoxygenic photosynthetic bacteria by distance-based grouping analysis of pufM sequences, Lett. Appl. Microbiol., 45, 639-645, 2007.

Zhang, G. I., Hwang, C. Y., and Cho, B. C.: Thalassobaculum litoreum gen. nov., sp. nov., a member of the family Rhodospirillaceae isolated from coastal seawater, Int. J. Syst. Evol. Micr., 58, 479-485, 2008. 